\title{
ECOTOXICOLOGICAL ASSESSMENT OF SEDIMENTS FROM THE PORT OF SANTOS AND THE DISPOSAL SITES OF DREDGED MATERIAL
}

\author{
Eduinetty Ceci P. M. Sousa' ${ }^{1}$; Denis M. S. Abessa ${ }^{2}$; Bauer R. F. Rachid ${ }^{3}$ \\ Marcia R. Gasparro ${ }^{l} \&$ Letícia P. Zaroni ${ }^{l}$ \\ ${ }^{1}$ Instituto Oceanográfico da Universidade de São Paulo \\ (Praça do Oceanográfico, 191, 05508-120, São Paulo, SP, Brasil) \\ ${ }^{2}$ Universidade Estadual Paulista Júlio de Mesquita Filho - Campus do Litoral Paulista \\ (Praça Infante Dom Henrique, s/n, 1330-900 São Vicente, SP, Brasil) \\ ${ }^{3}$ Fundação de Estudos e Pesquisas Aquáticas \\ (Av. Afrânio Peixoto, 412, 05507-000 São Paulo, SP, Brasil)
}

A bitract

The dredging of sediments from the Santos Channel is necessary to allow the navigation of ships operating in the Port of Santos. The disposal sites for such sediments are situated on the coastal zone, in front of the Santos Bay. The present paper aimed at evaluating the toxicity of sediments collected at the Santos Channel and at the former and current sediment disposal sites. Whole sediment tests with amphipods and elutriate assays with sea-urchin embryos were used. The samples from the Santos Channel were considered the most toxic: all the sediment samples from this area showed toxicity. Moreover, some samples from both former and new sediment disposal sites exhibited toxicity. Therefore, results showed that sediments from the studied areas present evidences of degradation; however, further studies are required to determine relationships between toxicity and contamination. Results also suggested that the disposal of dredged sediments should be re-evaluated.

$$
\text { RESUMO }
$$

\begin{abstract}
A dragagem dos sedimentos do Canal de Santos é necessária para permitir o trânsito de navios que operam no Porto de Santos. As áreas de disposição do material dragado estão situadas na zona costeira, em frente à Baía de Santos. Este estudo visou avaliar a qualidade dos sedimentos do Canal de Santos e das áreas de disposição atuais e antigas, utilizando testes de toxicidade de sedimento integral com anfípodos e de toxicidade de elutriatos com embriões de ouriço do mar. As amostras do Canal de Santos foram consideradas as mais tóxicas: todas as amostras dessa área foram consideradas significativamente tóxicas. Além disso, algumas amostras das áreas de disposição exibiram toxicidade. Os resultados mostraram, portanto, que os sedimentos apresentam evidências de degradação em sua qualidade, porém novos estudos devem ser conduzidos visando determinar as relações entre contaminação e toxicidade. Os resultados sugerem ainda que a disposição dos sedimentos dragados deva ser reavaliada.
\end{abstract}

Descriptors: Santos, Port of Santos, Sediment, Toxicity, Dredging.

Descritores: Santos, Porto de Santos, Sedimento, Toxicidade, Dragagem.

\section{INTRODUCTION}

The anthropic activities in Baixada Santista have led to the discharge of domestic and industrial effluents into its rivers and estuaries (Tommasi, 1979; Lamparelli et al., 2001). As observed in other estuaries (Belzunce et al., 2001; Carr et al., 1996; Chapman et al., 1987), contaminants are accumulating in the sediments of Santos (Lamparelli et al., 2001; Abessa, 2002; Medeiros \& Bícego, 2004); thus, such sediments may represent not only a sink but also a source of

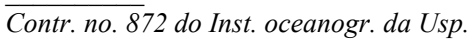

contamination to benthic organisms and the water column.

The Santos Estuarine System (SES) occupies a wide area of Baixada Santista, and comprises multiple contamination sources, such as the industries, the sewage outfalls, stormwater drains, the Port of Santos, illegal landfills and dumping sites, nonpunctual sources of sewage, among others. Its most critical region is the Santos Channel, where several contaminants, such as metals, aliphatic and polyaromatic hydrocarbons (PAHs), had already been detected in potentially toxic concentrations (Lamparelli et al., 2001; Abessa, 2002). 
The Port of Santos is situated along the banks of the Santos Channel. In order to keep the depth of the navigation channel and to allow the passage and manoeuvres of ships, sediments are continuously dredged all along the channel. According to the port authority, the management dredging operations may generate $4.5 \times 10^{6} \mathrm{~m}^{3}$ sediments or more. This volume would be added to the material dredged from the evolution basins, which may reach up to $100,000 \mathrm{~m}^{3} /$ month. A considerable portion of the dredged material is disposed in the sea.

The oceanic disposal of dredged sediments is a common practice worldwide; however, due to contamination, such activities have frequently become problematic and have been criticized. Some countries, as USA, Canada, European Union, have control programs for dredging and disposal activities (Andersen et al., 1998; Fostner \& Calmano, 1998; USEPA, 1998), and some of them follow the standards set forth by the United States Environmental Protection Agency (USEPA, 1998). According to these standards, the dredging and disposal procedures may vary, depending on the quality of sediments. However, despite the adopted dredging technique, several analyses must be carried out aiming to characterize these sediments, including ecotoxicological assessments.

Among the recommended procedures to evaluate the sediment toxicity, the whole sediment bioassays using amphipods and the liquid-phase using sea-urchin embryos are the most frequent (Lamberson et al., 1992), especially due to their sensitivity, practicality and low cost (Abessa, 2002). Solid phase bioassays aim to estimate the effects of contaminants to the benthic biota, as a result of the combination of all the exposure routes, whereas the elutriate bioassays were developed to assess the transference of contaminants and toxicity from sediments to the water column during the re-suspension process caused by the dredging and disposal operations (Lamberson et al., 1992; Abessa et al., 1998).

The present study aimed to assess the toxicity of sediments from the Port of Santos, in order to estimate the potential risks to the biota due to dredging and disposal activities. Another objective was to determine the quality of the sediments from the former and the current disposal sites, by using toxicity tests, and thus observe the existence of impacts due to the sediment disposal in such areas.

\section{Materials And Methods}

The sampling area (Fig. 1) comprised the Port of Santos (stations 1 to 6), the current sediment disposal site (stations 7 to 10), and the former disposal site (stations 11 to 13). Reference sediment was collected from Anchieta Island State Park, situated in Ubatuba $\left(24^{\circ} \mathrm{S}, 46^{\circ} \mathrm{W}\right)$. This site is considered uncontaminated and is routinely used as reference in studies conducted in the IOUSP Ecotoxicology Laboratory (Abessa, 2002; Rachid, 2002).

Sediment samples were collected using a Petersen grab sampler with $0.026 \mathrm{~m}^{2}$ area. From the retained material, $500 \mathrm{~mL}$ aliquots were separated for sedimentological analyses, transferred to plastic bags and immediately frozen. For the ecotoxicological evaluation, 3-L aliquots were immediately conditioned in ice, and kept refrigerated at $4^{\circ} \mathrm{C}$ until their use.

Grain size distribution analyses were conducted following the sieving method proposed by Suguio (1973). Total organic carbon (TOC), total nitrogen and sulphur contents were estimated by the use of a LECO Analyser CNS 2000.

Ecotoxicological analyses consisted of toxicity tests with elutriated and whole samples. An elutriate can be defined as a liquid phase extracted for fine particles, obtained after re-suspension of sediments in water (Oxford Reference, 1990). The toxicity tests with elutriates were developed specifically to evaluate the effects caused by the disposal of dredged material on the water quality, simulating, in short-scale, the transference of the toxic capacity from the sediments to the water as a consequence of such disposal. The sediment elutriates were extracted by 15 -min vigorous shaking (Lamberson et al., 1992), in hermetically sealed flasks. For each sample, $200 \mathrm{~mL}$ sediment were added to 800 $\mathrm{mL}$ filtered seawater, and then vigorously mixed for 30 minutes. The mixture was decanted for 2 hours, and the supernatant was separated for use in the bioassays.

The following elutriate dilutions were prepared, from dilution in filtered seawater: $25 \%, 50 \%$ and $100 \%$. The toxicity test was conducted following the technical standard L5.250 for assays using Lytechinus variegatus sea-urchin embryos (CETESB, 1992).

Adults of $L$. variegatus were collected from a rocky reef at Ponta da Espia, in Ubatuba, by snorkelling and then transported to the laboratory. Initially, the spawning was inducted by the injection of $3 \mathrm{~mL} \mathrm{KCl} 0.5 \mathrm{M}$ into the celomatic cavity of 3 males and 3 females. Ovules were collected in beakers containing filtered seawater, and after an integrity check, they were grouped in a single beaker. The sperm was collected by using a droplet, and assembled in a single beaker kept in ice. After activation, by diluting $0.5 \mathrm{~mL}$ sperm in $24.5 \mathrm{~mL}$ seawater, the fertilization took place, by adding $2 \mathrm{~mL}$ sperm solution into the ovule solution.

The toxicity tests were conducted in test tubes, containing $10 \mathrm{~mL}$ test-solution and approximately 300 eggs. Four replicates were used for 
each concentration, and the experiment was maintained at $25 \pm 2^{\circ} \mathrm{C}$ and 12 -hours photoperiod. After $24 \mathrm{~h}$, the test was finished and the contents of each replicate were fixed by addition of $4 \%$ formaldehyde. Afterwards, the embryonic development rates were estimated by counting the larvae under microscope.

The whole-sediment test used the amphipod Tiburonella viscana as a test-organism. Individuals were collected from Engenho d'Água beach, in Ilhabela, using a manual dredge. The animals were transported to a laboratory and acclimated for 3 days in tanks containing filtered seawater and reference sediment, at $25 \pm 2^{\circ} \mathrm{C}$, under constant lighting and aeration. The test method was described by Melo \& Abessa (2002). The assay was conducted in 1L high density polyethylene chambers. Three replicates were prepared for each sample, by adding a $2 \mathrm{~cm}$ layer of sediment, $750 \mathrm{~mL}$ filtered seawater and 20 amphipods. The experiment was kept under constant aeration and lighting, at $25 \pm 2{ }^{\circ} \mathrm{C}$. Physical-chemical water parameters $(\mathrm{pH}$, total dissolved ammonia, salinity, dissolved oxygen) were measured daily. After 10 days, the test was over. The contents of each replicate were sieved in $0.5 \mathrm{~mm}$ net and the number of survivors and dead ones was counted.
The data of both bioassays were checked for variance homogeneity and normality by the Bartlett and Chi-Square tests, respectively, and were then analyzed by the one-tailed t'test (Zar, 1996), in order to determine significant differences to the reference sample. Correlation analyses were applied to compare results of both toxicity tests.

\section{REsults AND Discussion}

The results of the sedimentological analyses are shown in Table 1. Based on the grain size distributions, sediments could be classified from silty clays to sands. Sediments from the port were finer and organically richer than those from the disposal sites, a fact which could be expected due to the occurrence of mangroves inside the Santos Estuarine System. However, samples 11 and 12 (both located close to the former disposal site) showed a higher percentage of fines. Once the current and hydrodynamic models for the Santos Bay indicate transport towards East (Harari \& Camargo, 1997; Harari et al., 2000), where the former disposal site is located, the present disposal activities may be influencing the old disposal area.

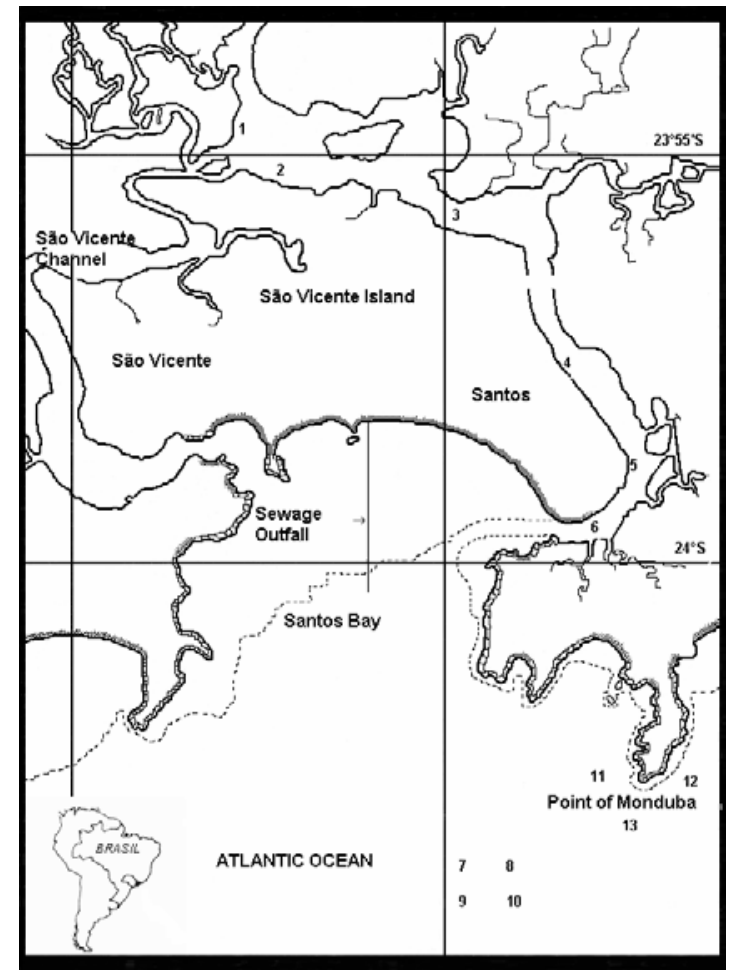

Fig. 1. Study area showing the sediment sampling stations. 
Table 1. Grain size distribution, Shepard classification and contents of Total Organic Carbon (TOC), Sulphur (S) and Nitrogen $(\mathrm{N})$ in the sediments from Santos.

\begin{tabular}{|c|c|c|c|c|c|c|c|}
\hline \multirow{2}{*}{ Station } & \multicolumn{3}{|c|}{$\%$} & \multirow{2}{*}{ Classification (Shepard, 1954) } & \multicolumn{3}{|c|}{$\%$} \\
\hline & Sand & Silt & Clay & & TOC & $\mathbf{S}$ & $\mathbf{N}$ \\
\hline 1 & 11.46 & 51.79 & 36.75 & silty clay & 2.80 & 0.89 & 0.20 \\
\hline 2 & 8.82 & 33.16 & 58.02 & silty clay & 0.79 & 0.13 & 0.07 \\
\hline 3 & 2.12 & 43.50 & 54.38 & silty clay & 2.14 & 0.62 & 0.16 \\
\hline 4 & 29.27 & 40.42 & 30.31 & clay-sandy silt & 1.03 & 0.34 & 0.09 \\
\hline 5 & 0.80 & 55.32 & 43.88 & silty clay & 2.37 & 0.64 & 0.22 \\
\hline 6 & 6.40 & 54.46 & 39.14 & silty clay & 2.53 & 0.43 & 0.27 \\
\hline 7 & 14.82 & 49.82 & 35.36 & silty clay & 1.39 & 0.55 & 0.12 \\
\hline 8 & 42.13 & 44.73 & 13.14 & sandy silt & 0.63 & 0.18 & 0.08 \\
\hline 9 & 10.22 & 37.98 & 51.50 & silty clay & 1.96 & 0.58 & 0.14 \\
\hline 10 & 84.29 & 10.78 & 4.93 & sand & 0.22 & 0.05 & 0.06 \\
\hline 11 & 45.53 & 49.58 & 4.89 & sandy silt & 0.21 & 0.03 & 0.05 \\
\hline 12 & 65.23 & 24.98 & 9.78 & silty sand & 0.86 & 0.09 & 0.07 \\
\hline 13 & 99.96 & 0.04 & 0.00 & sand & \multicolumn{3}{|c|}{ not measured } \\
\hline Reference & 98.33 & 1.23 & 0.47 & sand & 0.86 & 0.13 & 0.05 \\
\hline
\end{tabular}

In the elutriate toxicity, samples from stations 1,5 and 6 were considered significantly toxic in all the tested dilutions, whereas elutriate from station 3 produced significant toxicity at $100 \%$ and $50 \%$ concentrations. These sediment samples were collected at the Port of Santos (Fig. 2), and such results show that these sediments, when re-suspended may possibly transfer toxicity to the water column, at least in laboratory conditions. Nowadays, the dredging activity is the main cause of sediment re-suspension in the Santos Channel, followed by transit of large ships. This shows that the channel dredging is necessary, but, on the other hand, indicates that such activity must be controlled, and that some procedures should be avoided, as the overflow return to the environment, for example.

The whole sediment toxicity test produced a more severe result, and most of the samples were considered toxic. Significant amphipod mortalities occurred for animals exposed to the sediments from stations $1,2,3,4,5,6,7,10,11$ and 13 , whereas sediments from stations 8,9 and 12 did not produce adverse response in the exposed organisms (Fig. 3). Surprisingly, two samples from the former sediment disposal site presented toxicity (St. 11 and 13), corroborating the results of sedimentological analyses which suggested the possibility of sediments being transported from the current disposal site toward that area.

When results of both toxicity tests are compared (Table 2), they reveal that most samples presented toxicity in at least one assay. Samples from stations 1, 3, 5 and 6 were toxic in both tests. Sediments from stations 2, 4, 7, 10, 11 and 13 presented toxicity only in the whole sediment assay, whereas samples from stations 8, 9 and 12 were nontoxic. Moreover, the amphipod mortalities presented positive correlations to the rates of bad embryonic development in $100 \%(\mathrm{r}=0.6 ; \mathrm{p}<0.05), 50 \%(\mathrm{r}=0.56$; $\mathrm{p}<0.05)$ and $25 \%(0.48 ; \mathrm{p}<0.1)$ dilutions of the elutriate test, suggesting that the causes of toxicity may be the same.

According to studies regarding the geochemistry of sediments from SES and adjacent areas (Abessa, 2002; Medeiros \& Bícego, 2004; Lamparelli et al., 2001), the Santos Channel presents high levels of metals, PAHs, aliphatic hydrocarbons, chlorinated hydrocarbons and other contaminants, whereas the region around the former and current disposal sites show variable levels of contaminants. Thus, our results are compatible with the available geochemistry data. Moreover, the observed toxicity is in agreement with previous studies for the Santos Channel (Abessa, 2002; Abessa et al., 1998; 2001). 


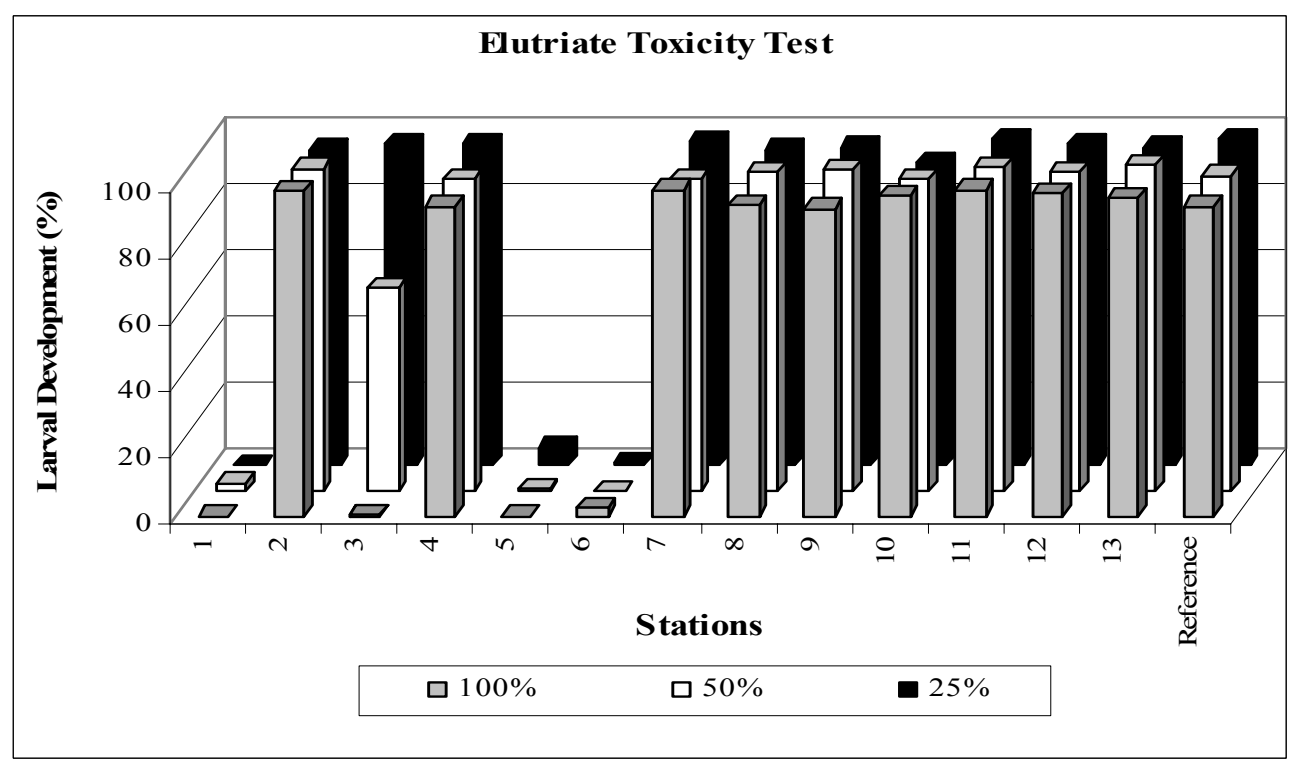

Fig. 2. Results from the elutriate toxicity test, expressed as normal L. variegatus embrionic development rate.

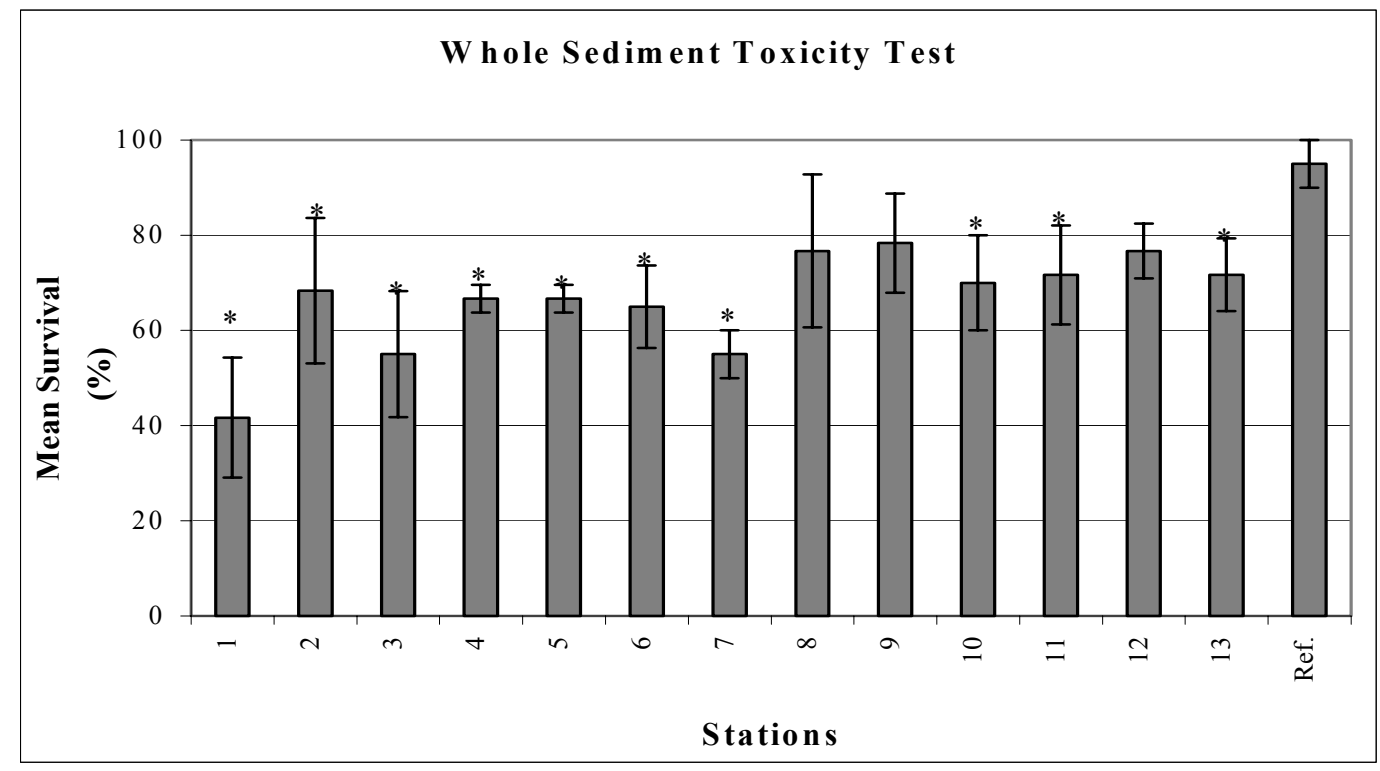

Fig. 3. Result from the whole sediment toxicity test, expressed as $T$. viscana means survival, where * $=$ significantly different from the reference group $(\mathrm{p}<0.05)$. 
Table 2. Sediment sample classification according to its toxicity.

\begin{tabular}{ccc}
\hline \hline & Sample classification & \\
\hline Station & Elutriate & Whole sediment \\
& & \\
\hline $\mathbf{1}$ & toxic & toxic \\
$\mathbf{2}$ & not toxic & toxic \\
$\mathbf{4}$ & toxic & toxic \\
$\mathbf{5}$ & not toxic & toxic \\
$\mathbf{6}$ & toxic & toxic \\
$\mathbf{7}$ & toxic & toxic \\
$\mathbf{8}$ & not toxic & toxic \\
$\mathbf{9}$ & not toxic & not toxic \\
$\mathbf{1 0}$ & not toxic & not toxic \\
$\mathbf{1 1}$ & not toxic & toxic \\
$\mathbf{1 2}$ & not toxic & toxic \\
$\mathbf{1 3}$ & not toxic & not toxic \\
& & toxic \\
\hline
\end{tabular}

The results obtained clearly confirm that sediments from the Port of Santos presented poor quality, and all samples collected in that area produced adverse effects, according to at least one toxicity test. Furthermore, two samples from the former sediment disposal site and two from the current one were toxic. Ecotoxicological tests showed that sediments from the Port are toxic and have potential to transfer toxicity to the water column; therefore, their disposal into the ocean can also produce adverse effects to the ecosystem and is not recommended.

Moreover, for the disposal area, a study identified and modelled the dispersion plume (Leitão et al., 2001), showing that the affected area is broad and extends towards Northeast. Probably, the currents transport contaminants transferred to the water column and negatively influence the adjacent area.

The toxicity data provide an ecological meaning to the contamination data obtained by other authors in Santos (Lamparelli et al., 2001; Abessa, 2002; Medeiros \& Bícego, 2004), especially for the internal portion of the SES. The toxicity is compatible to the geochemical data and corroborates the evidence of environmental degradation. Therefore, adjustments in sediment dredging and disposal procedures should be taken aiming at the reduction of environmental risks produced by these activities.

In areas like Santos, where multiple contamination sources are installed and the contaminant concentrations are critical, the use of controlled techniques and legal enforcements is advisable for both dredging and disposal, together with a program for monitoring the dredged areas and the disposal sites continuously, preferably following international standards (USEPA, 1998). A study regarding some alternatives to manage the contaminated sediments of the Piaçaguera Channel has been recently carried out (FUNDESPA, 2002), and can be a model for further evaluations conducted in the Port of Santos. Results show that, for the purpose of dredging and disposal, sediments must be characterized not only chemically but also ecotoxicologically, as a way to effectively evaluate their quality.

Another desirable policy for the SES is the implementation of a more rigid emission control. Although the pollution control program performed by the State Environmental Regulatory Agency (CETESB) has successfully reduced the quantity of pollutants discharged into the system, sediments are still contaminated. The environmental recovery of the region can only be achieved if contamination sources are totally and effectively controlled.

\section{REFERENCES}

Abessa D. M. S.; Sousa, E. C. P. M.; Rachid, B. R. F.; \& Mastroti, R.R. 1998. Use of the burrowing amphipod Tiburonella viscana as tool in marine sediments contaminantion assessment. Braz. Archs Biol. Technol., 41(2):225-230.

Abessa, D. M. S.; Sousa, E. C. P .M.; Rachid, B. R. F. \& Mastroti, R.R. 2001. Sediment toxicity in Santos estuary, SP-Brazil: preliminary results. Ecotoxicol. Environ. Restoration, 4(1):6-9.

Andersen, H. V.; Kjolholt, J.; Poll, C.; Dahl, S. O.; StuerLauridsen, F.; Pedersen, F. \& Bjornestad, E. 1998. Environmental risk assessment of surface water and sediments in Copenhagen Harbour. Wat. Sci. Technol., 37(6-7):263-272.

Belzunce, M. J.; Solaun, O.; Franco, J.; Valencia, V. \& Borja, A. 2001. Accumulation of organic matter, heavy metals and organic compounds in surface sediments along the Nervión Estuary (Northern Spain). Mar. Pollut. Bull., 42(12):1407-1411.

Carr, R. S.; Chapman, D. C.; Howard, C. L.; Biedenbach, J. \& M. 1996. Sediment quality triad assessment survey of the Galveston Bay, Texas system. Ecotoxicology, 5:341364.

CETESB. 1992. Água do mar - Teste de toxicidade crônica de curta duração com Lytechinus variegatus Lamarck, 1816 (Echinodermata: Echinoidea). Norma Técnica CETESB, L5.250, São Paulo. 16p.

Chapman, P. M.; Dexter, R. N. \& Long, E. R. 1987. Synoptic measures of sediment contamination, toxicity and infaunal community composition (the Sediment Quality Triad) in San Francisco Bay. Mar. Ecol. Progr. Ser., 37:75-96. 
Forstner, U. \& Calmano, W. 1998. Characterization of dredged materials. Wat. Sci. Technol., 38(11):149-157.

FUNDESPA - Fundação de Estudos e Pesquisas Aquáticas. 2002. Estudo ambiental para viabilização da obra de dragagem do canal de acesso e baía de evolução dos terminais marítimos privativos e de uso misto de Cubatão. Relatório Final - Síntese. São Paulo. 65 p.

Harari, J. \& Camargo, R. 1997. Simulações da circulação de maré na região costeira de Santos (SP) com modelo numérico hidrodinâmico. Pesquisa Naval, 10:173-188.

Harari, J. Camargo, R. \& Cacciari, P. L. 2000. Resultados da modelagem numérica hidrodinâmica em simulações tridimensionais das correntes de maré na Baixada Santista. Revta. Bras. Rec. hidr., 5(2):71-87.

Lamberson, J.O.; Dewitt, T.H.; Swartz, R.C. 1992 Assessment of sediment toxicity to marine benthos. In: Burton, G.A. ed. Sediment Toxicity Assessment. Chelsea: Lewis Publishers. p.183-211.

Leitão, J. C.; Silva, A. \& Ferreira, P. 2001. Modelação matemática da deposição de dragados na zona costeira do Estado de São Paulo - Brasil. In: Seminário sobre a Hidroinformática em Portugal. Lisboa, 15-16 de novembro, LNEC. CD-ROM. $18 \mathrm{p}$.

Lamparelli, M. L.; Costa, M. P.; Prósperi, V.A.; Bevilácqua, J. E.; Araújo, R. P. A.; Eysink, G. G. L. \& Pompéia, S. 2001. Sistema Estuarino de Santos e São Vicente. Relatório Técnico CETESB, São Paulo. 178p. Available at $<$ www.cetesb.sp.gov.br $>$.

Medeiros, P. M. \& Bícego, M.C. 2004. Investigation of natural and anthropogenic hydrocarbon inputs in sediments using geochemical markers. I. Santos, SPBrazil. Mar. Pollut. Bull., 49:761-769.

Melo, S. L. R. \& Abessa, D. M. S. 2002. Testes de toxicidade com sedimentos marinhos utilizando anfípodos como organismo-teste. In: Nascimento, I.; E.C.P.M. Sousa; M.G. Nipper eds. Ecotoxicologia Marinha: Aplicações no Brasil. Salvador: Editora Artes Gráficas. p.163-178.
Oxford Reference. 1990. A Concise Dictionary of Chemistry. New York: Oxford University Press, 111p.

Shepard, F. P. 1954. Nomenclature based on sand silt-clay ratios. Journal Sediment Petroleum, 24:151-158.

Suguio, K. 1973. Introdução à Sedimentologia. São Paulo: Edgar Blücher; EDUSP. 317p

USEPA - U.S. Environmental Protection Agency. 1998. Evaluation of dredged material proposed for discharge in waters of the U.S.-Testing Manual. EPA-823-B-98-004, Washington, DC.

Zar, J. H. 1996. Biostatistical Analysis, $3^{\text {rd }}$ ed. New Jersey: Prentice-Hall. 662p.

\section{Sources of Unpublished Material}

Abessa, D. M. S. 2002. Avaliação da qualidade de sedimentos do Sistema Estuarino de Santos. Tese de Doutorado. Universidade de São Paulo, Instituto Oceanográfico, $290 \mathrm{p}$.

Rachid, B. R. F. 2002. Avaliação ecotoxicológica dos efluentes domésticos lançados pelos sistemas de disposição oceânica da Baixada Santista. Tese de Doutorado. Universidade de São Paulo, Instituto Oceanográfico. 286p.

Tommasi, L. R. 1979. Considerações ecológicas sobre o Sistema Estuarino de Santos, São Paulo. Honorary Professor Thesys. Universidade de São Paulo, Instituto Oceanográfico. 2 vols.

(Manuscript received 22 June 2005; revised 17 April 2006; accepted 12 March 2007) 